\title{
Nyre på vandring
}

Ut fra min erfaring mangler helsevesenet kjennskap til symptomatisk vandrenyre.

Se kommentar side 439

Da jeg var ti år gammel, i 1966, ble min venstre nyre fjernet. Årsaken var hydronefrose etter mange betennelser pga. refluks. Siden levde jeg et normalt liv frem til høsten 2003, da jeg merket ubehag i høyre flanke og lyske. Jeg gikk en periode med dump, diffus, verkende smertefølelse.

Våren 2004 merket jeg forandring. Høyre nyrelosje føltes sår, det var vondt å le, å snu seg og å gå, og jeg ble sliten av å sitte på kontorstol og av å stå.

Jeg relaterte smertene til gjenværende nyre, da jeg syntes jeg kjente igjen symptomene. Urinen var grumsete, og jeg oppsøkte lege med mistanke om begynnende nyrebekkenbetennelse. Blodtrykket var forhøyet, urinstiks viste blodspor, men ikke puss, og kreatininnivået lå innenfor grense- verdiene. Dagen etter var jeg symptomfri, og utredningen ble stoppet. En uke senere oppsøkte jeg igjen lege og ble utredet for nyrestein, men konkrement ble ikke påvist.

\section{Plagene øker}

I de neste årene fikk jeg tiltakende plager. Jeg ble grundig utredet, med tallrike undersøkelser - urografi, renografi, CT av nyre og øvrige abdominalorganer - men årsaken til plagene ble ikke funnet. Jeg fikk smertestillende medikamenter, som ofte ikke lindret.

Røntgenundersøkelser viste at gjenværende ureter hadde betydelig kalibervariasjon, og nyrebekkenet var utvidet.

Urinanalyser påviste intermitterende hematuri, det ble tidvis målt forhøyet blodtrykk og høy puls samt registrert en bilyd over hjertet. Grad av smerte og smertesymptomer varierte. Jeg var periodevis smertefri, men når smertene var på sitt verste, var jeg ukonsentrert, fikk taleproblemer, var svimmel og ør. Smertene var verst når jeg satt, og de kom gjerne etter at jeg hadde sittet stille noen timer. De avtok når jeg lå flatt eller var i aktivitet. I ren fortvilelse kunne jeg binde et tau stramt rundt magen, og det hjalp noe. Ved smerteanfall observerte jeg blodsprengte øyne og hovne mandler. Over tid ble huden i ansiktet rødmusset grunnet sprengte blodkar.

Jeg var helt eller delvis sykmeldt $i$ lange perioder. Utredningen stoppet opp gang etter gang. Det var belastende å møte til polikliniske undersøkelser og fortelle om symptomene, for så å reise udiagnostisert

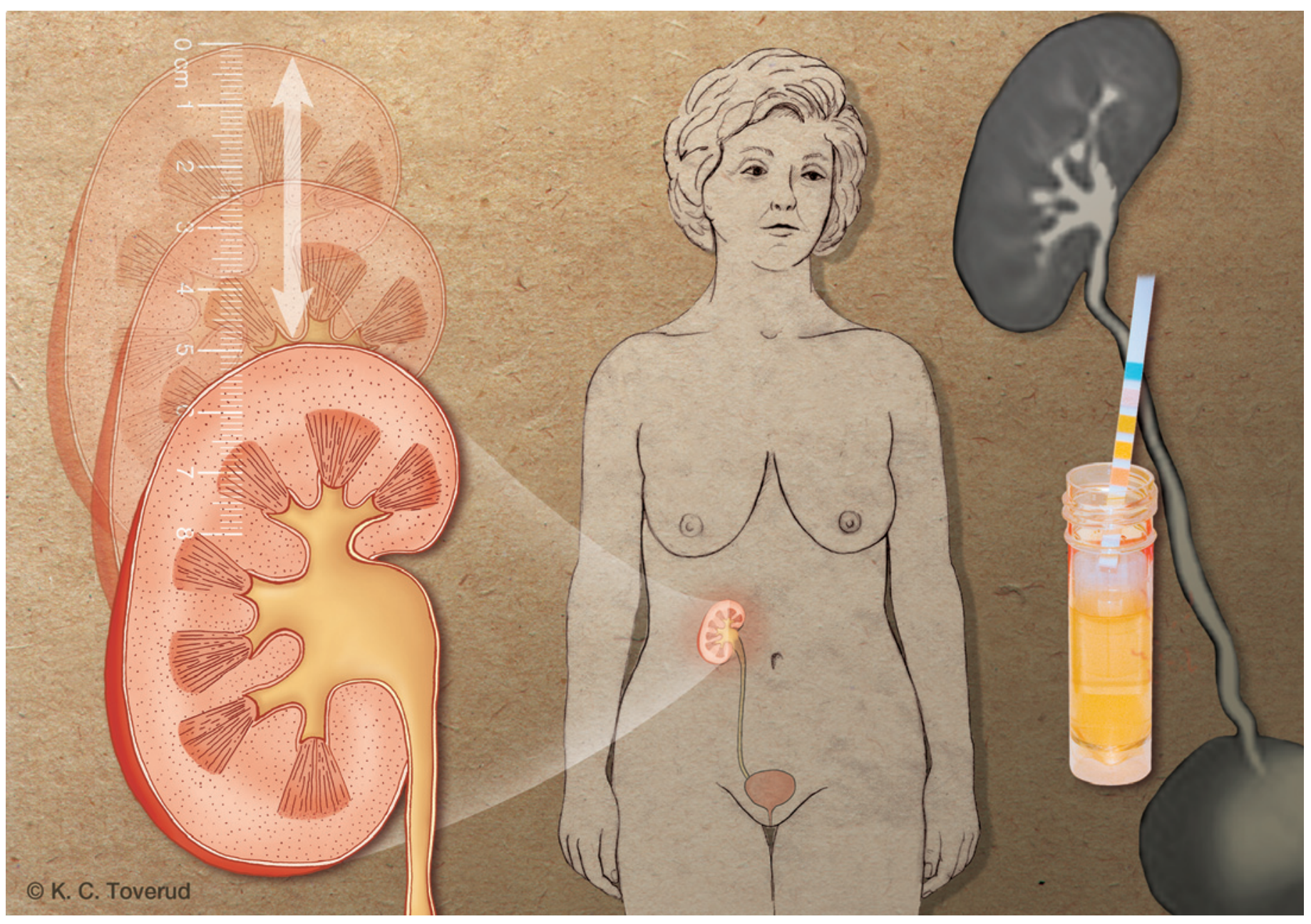


og ubehandlet hjem igjen. Jeg fikk flere ganger følelsen av ikke å bli trodd. Jeg forsto at jeg ikke kom til å få hjelp, siden jeg stadig fikk beskjed om at jeg måtte «lære meg å leve med» plagene mine. Jeg var ikke enig, smertene var for voldsomme. Flere ganger ble jeg forklart at plagene hadde psykiske årsaker.

Jeg måtte si fra meg arbeidet som gruppeleder på jobben og byttet arbeidsoppgaver i håp om at det kunne gi bedring, men det hjalp ikke. Jeg la meg tidlig om kvelden og klarte så vidt å stå opp og gå på jobb. Det føltes nedverdigende å sitte på jobben og være syk. Jeg fikk problemer med å fungere i familien, på jobben og sosialt ellers, følte meg utslitt og gikk ned i vekt.

\section{Kan det være nyren?}

Min datter er bioingeniør og undersøkte, sammen med overlegen ved laboratoriet der hun arbeidet, en urinprøve fra meg etter et smerteanfall. Den viste «rikelig med intakte erytrocytter, uttrykk for en postglomerulær hematuri». Overlegen hadde tidligere sett et tilfelle med symptomatisk vandrenyre (ren mobilis) og mistenkte at dette også kunne gjelde meg. Etter konferanse med urolog ble det kartlagt nærmere.

Det ble anbefalt røntgen i liggende og stående stilling ved smerteanfall, for om mulig å påvise redusert avløp fra nyren og for eventuelt å påvise mobil nyre. Jeg klarte aldri å få organisert røntgenundersøkelse ved smerteanfall pga. reiseavstand og åpningstider ved røntgeninstituttet. Det ble således ikke påvist eventuelt redusert avløp fra nyren. Ved urografi ble det konstatert mobil høyre nyre, først med nyreforflytning på $2,6 \mathrm{~cm}$, senere med $4,4 \mathrm{~cm}$. Renografi viste nyreforflytning på $4-5 \mathrm{~cm}$. Etter å ha lest mange artikler i engelskspråklige medisinske tidsskrifter om vandrenyre, ble jeg overbevist om at dette kunne være årsaken til mine invalidiserende plager.

Jeg ba om operasjon for mulig avbøting av plagene, men det ble avslått i 2008, da legene mente at man ikke hadde holdepunkter for at smertene skyldtes vandrenyre. Jeg var igjen på bar bakke - like syk som før og fullstendig utslitt. Arbeidsgiver aksepterte ikke lenger sykdommen min. Det ble stilt krav som jeg pga. plagene vanskelig kunne innfri, og jeg så meg selv på vei ut fra arbeidsforholdet. Jeg søkte om å bli utredet ved et sykehus med erfaring med tilstanden i Sverige, men søknaden ble avslått.

Jeg ga uttrykk for at jeg ikke lenger orket å leve med plagene. Operasjonen laparoskopisk nefropeksi ble til slutt tilbudt, på eget ansvar. Jeg ble operert i februar 2009, og kirurgen beskrev «multiple adheranser mellom colon og bukvegg på høyre side». Adheransene ble løsnet. Nyren ble festet så høyt i buken kirurgen klarte.

Etterpå ble de fleste smerteplagene borte.
Jeg har fått et mye bedre liv, og livet føles igjen verdt å leve. Jeg har lagt på meg, er fysisk aktiv, går tur, jogger og arbeider i $70 \%$ stilling. Urinen har vært klar og fin. Hematurien er borte. De sprengte blodkarene $i$ ansiktet er nesten borte, mandlene er ikke lenger hovne og blodtrykket er normalt.

Det virker som om symptomatisk vandrenyre er lite kjent blant leger i Norge, og det synes å mangle utredningsprosedyrer. Jeg vil tro det er flere enn meg som helt unødig har gått med slike forferdelige plager. Jeg håper at min historie kan være med på å gjøre diagnosen bedre kjent blant helsepersonell.

\section{Kari Tuft Stavnes}

kstavnes@online.no

Kvernberggata 39

Hønefoss

Kari Tuft Stavnes (f. 1956) er saksbehandler i Skatt Sør.

Mottatt 5.7. 2011, første revisjon innsendt 23.11 2011, godkjent 1.12. 2011. Medisinsk redaktør Erlend Hem.

\section{Symptomgivende vandrenyre kan både diagnostiseres og behandles}

Kari Stavnes gir en god beskrivelse av en tilstand som har vært gjenstand for mye diskusjon i medisinsk litteratur. Hun beskriver godt en del av de typiske ledsagersymptomene hun har opplevd, men enda bedre fortvilelsen over at hennes plager ikke blir gjenkjent og behandlet før etter mange år.

Hun mener tilstanden er lite kjent blant leger og dermed ikke blir diagnostisert. Vandrenyre er i nyere tid omhandlet i Tidsskriftet ved to anledninger $(1,2)$. Tilstanden går under mange navn: nefroptose, ren mobile, ren migrans, Wanderniere, floating kidney. Rundt forrige århundreskifte ble den (for) hyppig diagnostisert og operert, noe som ledet til at inngrepet, nefropeksi, kom i miskreditt. Nå finnes det bedre diagnostiske metoder slik at inngrepet kan begrunnes på en mer sikker måte (3).

\section{Smerter er hovedsymptom}

Nyrene beveger seg ved overgang fra liggende til stående stilling, dessuten ved hvert eneste åndedrag som følge av diafragmabevegelse. Hos enkelte kan bevegelsen være eksessiv og gi opphav til plager. Ofte angis at bevegelse på $>5 \mathrm{~cm}$ eller mer enn to virvelhøyder er patologisk. De fleste med så stor bevegelighet er uten symptomer, men det antas at $20 \%$ kan ha symptomer og behov for behandling (3). Smertene antas å være forårsaket av obstruksjon i overgangen nyrebekken-ureter, grunnet avklemming når nyren faller ned - med påfølgende trykkstigning, som kan lede til hydronefrose. Når nyren endrer leie, blir karstilken forlenget - med avsmalning av nyrearterien med påfølgende nyreiskemi, som i sin tur kan lede til hypertoni (Goldblatt-nyre) (3-5). Om tilstanden vedvarer over lang tid, antas den å kunne forårsake fibromuskulær dysplasi, med nyrearteriestenose til følge.

Den typiske pasient er en ung, slank kvinne som klager over varierende grad av smerter i høyre abdominalhalvdel eller flanke som typisk opptrer i stående stilling og under aktivitet, med lindring når hun legger seg ned. Noen kan typisk ha smerter når de ligger på venstre side, med lindring ved å ligge på høyre side. Noen pasienter opplever (gjentatte) nyrebekkenbetennelser.

Smerteangivelsen kan variere fra den kolikkartede (Dietls krise) til dumpe, stikkende smerter i stående eller sittende stilling med lindring når man ligger. Mange opplever kraftig kvalme, noen med brekninger. Hos slanke pasienter kan ofte nyren palperes under kostalbuen i stående stilling eller i kne-albue-leie, nyren er ofte palpasjonsøm og balloterer mer enn normalt $(3,6,7)$.

\section{Undersøkelse}

Ved undersøkelse kan man finne varierende grad av hematuri og hypertensjon, hos noen bare i stående stilling. Den typiske pasient er undersøkt for mistenkt nyresteinsanfall uten å få påvist nyrestein. 